\title{
Falling Between Two Cracks: The Indeterminate Character of Mid-level Government
}

\author{
Michiel S. de Vries
}

Published online: 7 March 2008

(C) The Author(s) 2008

\begin{abstract}
This article argues that the neglect of mid-level government among public administration scholars is regrettable because the investigation of developments within this level of governmental could shed new light on various core themes in public administration. In order to understand developments taking place at the local level, it is often necessary to investigate what is going on at the mid-level. This article concludes that public administration scholars should develop a general framework to judge the policies and position of mid level government, investigate whether the provincial level is the appropriate level for developing policies, conduct more independent evaluations of processes taking place at the mid-level layer of government; and conduct comparative research into the causal mechanisms that determine the needs for midlevel government.
\end{abstract}

Keywords Regional government - Comparative research · Public administration

In most countries, one or more intermediate levels of government exists between the local level and the national level of government. These are known under various names: Provinces (In French speaking countries), Provincia (in Spanish speaking countries), muhfazah (in Arabic countries), Ostan (Persia/Iran), Oblast (Russian), Regions (in many English speaking countries), Länder (f.i. Germany), Amter (Denmark), Wilaya (Afganistan and Algeria), Voïvodships (Poland) States (US), Concelhos (Portugal), Kraje (Czech Republic), Prefectures (Japan), Departements (France), Riksomraden (Sweden), Suurlahoeet (Finland), Regional Councils (New

This article was presented before as a paper at the IIAS/IASIA conference in Abu Dhabi, July, 9-14, 2007.

The empirical material for this article was collected by five master's students in public administration at the Radboud University Nijmegen, namely Maarten Dijk, Willem Dittrich, Henk-Jan Oosterhuis, Gersom Smit, and Tim Kersten.

M. S. de Vries $(\bowtie)$

Department of Public Administration, Radboud University Nijmegen,

Thomas van Aquinostraat 5, P.O. Box 9108, 6500 HK Nijmegen, The Netherlands

e-mail: m.devries@fm.ru.nl 
Zealand), or Comunidades autonomas (Spain), Eparchia (Greece). Only a few countries operate without such intermediate government (e.g. Iceland).

The functions, roles and responsibilities of these mid-level governments vary as widely as their names. Tasks that are performed in one country by municipalities or by national government are handled by the mid-level government in other countries. When a country is a federation, provinces often have more authority (e.g. Canada, Belgium, Argentina, Germany, India, Russia, UAE) while in unitary states, they are subordinate to the national level (the majority of countries in the world). In most of the latter countries, provinces are seen as local units, in some of the former they are viewed as constituent autonomous areas.

As a result of these divergent names, functions, and responsibilities, the question of how to judge mid-level government is difficult to answer. Furthermore, most scholars in public administration either investigate local or national government (Dowling 2003; Kahler and Lake 2003). The mid-level is seriously neglected. One reason is that mid-level government is often looked down upon with some disdain by scholars and by the other layers. It is viewed as a disturbing factor, which interferes in policies that are the formal responsibility of the national or the local level, and its added value is disputed.

No one really knows what to do with mid-level government and how to judge its performance and its proper role. The neglect of scholarly focus on this level is regrettable because the investigation of developments within this governmental layer could shed new light on various core themes in public administration, such as decentralization, intergovernmental relations, policy coordination, the budgetary process and public management. In order to understand developments taking place at the local level, it is often necessary to investigate what is going on at the mid-level. This paper addresses the following questions:

- What is known about the substantial merits of mid-level government?

- Are such merits determinative for-or are there other factors explaining - the existence, size, responsibilities and authority of mid-level government?

- What does a case study about the debate on provinces, such as that going on in the Netherlands, show in this regard?

- What could be the contribution of public administration in this regard?

\section{Some theoretical considerations}

Provinces are unities within a nation-state, but the character of this unity is indeterminate. It can be in terms of culture (specific dialect, customs and habits), historical background, such as a Duchy or a county; economic developmentmainly rural or urban; or in geographical terms. However, such differences are relative. Even within the smallest provinces in the Netherlands, for instance, differences can be substantial (i.e. between rural and urban areas), but the cultural differences between provinces can also be marginal. A survey of the main distinguishing characteristic of the province in which Dutch people live revealed that the majority of all people in all 12 provinces mentioned 'closeless' as the main feature of their own province in contrast to other provinces (Peters 2007). 
"Province" comes from the Roman Empire in which an area on behalf of ('pro') the central government of the empire is controlled ('vincere'). The classic origin still has an impact nowadays because provinces are often associated as areas outside the capital city, which are administratively controlled on behalf of the national government. In some countries, the capital city still is a separate entity next to the provinces (Belgium, Romania).

One would expect provinces therefore to be smaller than national states. This is self-evident, but if one looks at the largest provinces in the world namely Xingjian in China $\left(1,660,000 \mathrm{~km}^{2}\right)$ and Quebec in Canada $\left(1,542,056 \mathrm{~km}^{2}\right)$ they comprise an area larger than that of many countries (cf. The Netherlands $41,526 \mathrm{~km}^{2}$, France $674,843 \mathrm{~km}^{2}$ or even Peru 1,285,220 $\mathrm{km}^{2}$ ).

The classic idea about provinces still affects its present day position in unitary states. Its main function is to steer and control developments within the region on behalf of central government because the national state is too large to be controlled from the capital. This also provides the origin of the disputes between local government and provincial government. The former want to develop policies autonomously, but provinces are always involved, and they control and coordinate local developments. In The Netherlands, for instance, municipal budgets are controlled by the provinces, the responsibility over many policy areas is divided among local, provincial and national government, and when conflicts occur within or between municipalities, provinces are the first to try to coordinate.

From a positive point of view, provincial governments assist national as well as local governments. They assist national government because they sometimes control regions that are geographically distant from the capital and assist (especially small) local governments that are unable to develop the policies required by law on their own because they lack the expertise. Small localities often have problems in hiring specialized personnel, which is nevertheless required in order to give permits, control pollution, and to conduct safety controls. In such cases provinces can help out.

A second merit of provinces is related to so-called spill-over effects. Decisions made in one municipality often impact the citizens in neighboring municipalities. Frug (2000), for instance, points to the extraterritorial impact every city decision has, and the possible inconsistency of such decisions among different municipalities, not to mention the consistency between local and higher law affecting residents' rights in a negative way. In fact, there might be something like a tragedy of the commons (cf. Ostrom 1990), concerning local government when every village wants to have it own new housing estates, golf course, industrial area, theater and other services. Mid-level government exists in order to coordinate and conduct the planning on a regional level. This might prevent such inefficiencies; generate positive spill-over effects, internalize the external effects caused by uncoordinated policies; and increase efficiency by bringing about policy coordination. This is why many scholars are in favor of regional governance as a way of rationalizing local policymaking (e.g. Katz 2000; DiMento and Graymer 1991; Kresl and Gappert 1995; Jacob 1984; Schechter 1996).

Third, it is often pointed out that regional government has the advantage of the economy of scale. By combining local policies, regional governments can reduce the costs of service provision to the involved set of member municipalities, especially in case of technical services, garbage disposal, water, and sewer systems. 
There are also many arguments against provincial involvement. Prud'homme (1995) addressed the advantages of giving powers to national government as opposed to regional government. The merits he mentions in this regard include the possibilities to redistribute resources from richer to poorer regions, the possibility of destructive competition between regions in order to attract investments, the impossibility for macro economic policy if taxes were collected at the sub-national level, the problems of what he called financial perversities, in case a higher government level is known to take care of problems when a sub-national government neglects the problem; the inefficiency of allocation and taxation because of elections, the economies of scale, the level of corruption which, according to Prud'homme might well be lower on a national than on sub-national level, the difficulties in designing a good transfer system between governmental levels, the difficulties of collaboration between governmental levels, and the indeterminate effectiveness of several instruments in that regard, like mandates, constraints, guidelines, floors and ceilings, coordination mechanisms, contracts and so on and so forth (Prud'homme 1995).

There are many public administration scholars favoring the subsidiarity principle and promoting decentralization to the lowest level possible, that is, the local and not the regional level. The advantages are often mentioned and well-known; more efficiency, tailor-made policies, and less red tape. Furthermore, being closer to the citizen, this would provide more opportunities for participation and citizen empowerment, resulting in flexibility and a high potential for learning. There would also be less redundancy in service delivery when it is based on knowledge about the local context. However, as argued before, these arguments are often no more than disputable hypotheses, which can be sufficiently countered by opposing claims. In addition, the preference for decentralization or centralization shifts through time and is dependent on the features of the existing situation (de Vries 2000). Furthermore, decentralization, as well as centralization, can have very different effects in different circumstances (Andrews and de Vries 2007).

The merits of the position of provinces in relation to municipalities as presented above only apply if local governments are willing to give up some of their authority and responsibilities. Such a willingness among local governments is unlikely given the suspicion about the motives of provinces' actions - do the actions benefit local government as well or only the provinces and/or the national government? This lack of inclination can be explained further because the division of power between governmental layers can be characterized as a zero sum power game, in which more powers to one level by definition implies less powers for at least one of the other levels. The idea that the local level would be willing to share its powers and responsibilities is based on the assumption of congruent interests among local, provincial and national levels. This assumption is at least disputable. This implies that the different notions about the desired position of the provinces might be more dependent on strategic issues than on rational considerations.

The varying size, functions and responsibilities of, and the distinct views thereon highlight the indeterminate position of mid-level government. Questions arise about the optimal scale of a territory in order to capture economies of scale, reduce spillover effects and help local governments. The question can be posed whether there should be a mid-level government and whether developments within provinces, e.g. 
mergers among municipalities, and developments in the context of provinces, e.g. globalization, have reduced or increased the need for a mid-level government.

The answer to this question might also depend on other factors. One can point to the size of countries, the distance between center and periphery and difficulties of communication among them, the heterogeneity of countries, the average size of municipalities, the variance in the severity of problems, the composition of regional economies and cultural diversity, that would determine whether an intermediate level with more or less tasks, responsibilities and authority between the national and local level is needed.

As sound as this may look from a rational point of view, the argument lacks explanatory power in practice. Given the huge variation in size, functions, powers and responsibilities of the provincial level in different countries, there seem to be other reasons than rational ones for specific arrangements. It is remarkable that in many countries, the number of provinces has remained the same despite significant changes in the context and within their territory. Third and fourth level governments are even found in the smallest countries and neither changes in the average size of municipalities nor the other factors mentioned have affected the position of the midlevel governments up to now. To give just one example, the factors mentioned in the literature cannot explain why, for instance, Gabon has more provinces than South Africa, or why very distinct countries like The Netherlands, Rwanda and Uzbekistan have the same number of provinces.

An international comparison of the position of provinces, points to the predominance of politico-historical factors, path dependencies and institutional resilience as the more important factors explaining the number and size of such governments.

This concise discussion results in the research question: What is the weight of rational considerations compared to politico-historical factors in the explanation of the existence of provinces as such, their size, powers and responsibilities?

Unfortunately, I was unable to find the answer to this question in the existing literature. In the huge bulk of the literature on good governance (as promoted by the World Bank, IMF, and UNDP), entrepreneurial governance (Osborne and Gaebler 1992), competitive governance, enabling governance, and participatory governance (for an overview see among others Guy Peters 1996, or Denhart 2002), the role of mid-level government is neglected.

In the alternative conceptualization of sound governance (Farazmand 2004), dimensions of sound governance could well be used to examine and explain the varying role of mid-level government in different countries, e.g. process, structure, cognition and values, constitution, organization and institution, management and performance, policy, sector, international and globalization forces, and ethics, accountability and transparency (Farazmand 2004, p. $13 \mathrm{ff}$ ). With regard to organization and institution, he asks how well these organizations operate in coordination with other institutions of government (Farazmand 2004) and he states that institutions without sound organization are fragile and doomed to failure since they cannot perform and do what they have been created to do. This failure also leads to policy failures, structural failures, and process failures of the governance system; hence to unsound governance (p. 15). This could well be the explanation for the fragile position of mid-level government in many countries. While Farazmand mentions that the issue of sound governance includes local, national, regional and 
international governance as well as global levels (Farazmand 2004: p. 14), the discussion of governance on the mid-level is restricted to the innovations taking place in intergovernmental relations in the USA (see the chapter by Nice and Grosse in Farazmand 2004). The attention in the remainder of the book is focused especially on local and national governance.

\section{The case: intergovernmental relations in The Netherlands}

To illustrate the importance of mid-level government in intergovernmental relations, this section presents the example of the changing position of the provinces in The Netherlands. At one time, the provinces made up the most powerful governmental layer (see de Vries 2004). Their position has declined over the years and recently the position of provinces in The Netherlands has come under pressure. Very low turnouts at provincial elections, their invisibility among the public, their ambitions that stretch far beyond their responsibilities as provided in law, the suspicion about their motives by the local and national levels, and the increasingly dominant idea that they are a redundant level of government have made the province the least popular governmental organization.

This debate seems to have entered a new phase with the national government that was formed in 2007. Now the first signs of a coalition between national and local government against the provincial level are visible. As early as 2006, the Dutch Association of Municipalities wrote a letter to the Home Secretary pleading for lessening the role of the provinces in those policies in which other governmental layers are primarily responsible. The provinces were not amused and have since suspended all contacts with the municipalities and their association.

The newly established (March 2007) national government, i.e. the Home Secretary, with a minister of the interior, who was previously a mayor of one of the larger cities, urged the provinces to restrain themselves in developing new policies. She told them to do only those things they are required to do by law and to refrain from all of those policy areas in which other governmental layers have prime responsibility. The new coalition agreement reads, rather neutrally but still clearly: "The coalition intends to diminish the administrative crowdedness. This is possible by reducing the number of governmental layers involved in certain policy areas to a maximum of two" (Coalition Agreement, May, 2007).

While writing this article, the first hostile reactions towards the Home Secretary appeared. The status and money involved, the vested interests, and the criticism from national government have irritated the elected provincial deputies. One of them said: 'the existence and rights of provinces are undisputed... The question is: Should there be a Minister of Neighborhoods?... She should not interfere in affairs which are conducted by Provinces within the margins of the law' (Gelderlander, Gazette, July, 14th 2007).

Formally he was right. By law the responsibility to manage and govern developments within the province is left to the provincial government itself. Provinces are allowed to develop any plans they desire for the benefit of the inhabitants living in their territory. However, there are only a few specific tasks for which provinces have the prime responsibility by law. Examples are tasks with regard to the control of municipal 
finances, technical tasks related to water management, provincial roads, public space, the environment, and some minor tasks concerning for instance, ambulances, youth care and juvenile institutions.

Notwithstanding this minor position, Dutch provinces have always developed policies in policy areas where they don't have any responsibilities. This has been done in policy areas such as economic development, housing, welfare, culture, health care, sports, and poverty, by which they try to steer, alter, redirect and in general standardize municipal policies, and induce local authorities to conduct experiments and pilots (Peters 2007a, b). This is the main reason why the provinces are accused by the municipalities of unwanted interference instead of involvement, and for complicating, duplicating, and standardizing instead of coordinating the local policies.

The case study presented below addresses this conflict and tries to describe and explain it within the main research question stated above. First, we give a concise overview of the situation in the Netherlands. Next we address the main actors, their position towards the provinces and their arguments, and finally we analyze these arguments and conclude whether they are predominantly rational or political in nature.

\section{Some background information}

The Dutch state calls itself a decentralized unitary state. It has approximately 16 million inhabitants, 12 provinces and 458 municipalities. The number of municipalities has diminished substantially as a result of consolidations. The reduction can be seen in Table 1 .

Especially after 1960, the number of municipalities decreased at an accelerated rate to about half the previous number. At present, there are plans to reduce the number even more toward approximately 250 municipalities, with the goal of developing larger, better equipped municipalities, each having at least 30,000 inhabitants.

The number of provinces has not changed significantly over the years. In 1986, the province of Flevoland was added as a result of land reclamation from the sea. As for the other provinces, they have existed for approximately 500 years. At one (glorious) time (seventeenth and eighteenth century), they were the most powerful institutions in The Netherlands. They collected their own taxes, they had their own currency, had veto power in national decision making, and they ruled the

Table 1 The reduction of municipalities in The Netherlands

Source: own research, partly based on Boogers 2000

\begin{tabular}{lll}
\hline Year & Number & Decrease (\%) \\
\hline 1900 & 1,121 & - \\
1910 & 1,121 & - \\
1920 & 1,110 & 1 \\
1930 & 1,078 & 3 \\
1940 & 1,054 & 2 \\
1950 & 1,015 & 4 \\
1960 & 994 & 2 \\
1970 & 913 & 8 \\
1980 & 811 & 11 \\
1990 & 672 & 17 \\
2000 & 504 & 25 \\
2007 & 458 & 10 (in \\
& & 7 years) \\
\hline
\end{tabular}


Netherlands in a similar way as the member states in the European Union nowadays make decisions in the EU (See de Vries 2004). After the French occupation in the early nineteenth century, the establishment of the Kingdom of The Netherlands in 1815, and the acceptance of the Constitution in 1848, the role of the provinces became the polar opposite of what they once were, that is, they became the weakest level (see de Vries 2004). The national and local government viewed the provinces with fear that they would once again become powerful, and most of the responsibilities and powers were concentrated in the hands of the nation-state and the municipalities. Since then, little has changed for the provinces and they obtained very few new responsibilities even though the huge changes were visible in the public sector as a whole, and the large increase of public expenditures in general.

Total governmental expenditures is nowadays about 110 billion euros (excluding social transfers and care), of which about half is spent by municipalities and only $5 \%$ by the provinces. Both municipalities and provinces receive about $80 \%$ of the finances they need from the national government through general or specific grants. The sub-national levels are barely able to collect taxes on their own and are almost completely dependent on national government for their income. The figures are presented in Table 2.

It is clear that the bulk of the public expenditures is at the national and local levels. In fact, one can say that The Netherlands has developed into what is called a dual state, with only a very minor position for the intermediate level, i.e. the provinces.

The participants in the debate about the provinces

In The Netherlands several actors are involved in the debate about the appropriate role of the provinces. These actors include the provinces themselves and the national association of provinces (IPO), the municipalities and the Dutch association of municipalities (VNG), the National government and especially the Home secretary (Biza), the EU, especially the committee of the Regions and the Council of Europe, and a number of public administration scholars, writing about the provinces, often by commissioned for one of the above actors. Because it is impossible to address all the publications on this issue, we focus on those actors who were most involved in the discussion.

First there is IPO. The goal of this organization is to improve the conditions under which provinces act and the stimulation of innovation at the provincial level. IPO is the interest group of the 12 provinces (IPO 2006a: 5). The organization aims for a

Table 2 Public expenditures in The Netherlands (Billions of euro)

\begin{tabular}{llll}
\hline & 2005 & 2006 & 2007 \\
\hline National level & $92.6^{\mathrm{a}}$ & $102.0^{\mathrm{a}}$ & $109.5^{\mathrm{a}}$ \\
Provincial level & 4.5 & 4.7 & 5.4 \\
Local level & 42.3 & 43.6 & 46.1 \\
GDP & 474.0 & 494.0 & 515.0 \\
\hline
\end{tabular}

a Including transfers to sub-national government and excluding social transfers and care expenditures (together about the same as the total public expenditures)

Springer 
strong and dominant position of provinces. The viewpoints are based on many commissioned scholarly reports, such as that from the Geelhoed Commission (after the first writer) and essays written by, for instance, Toonen.

The association of municipalities is the interest group acting on behalf of local governments. This organization aims for consolidating and the strengthening the position of its members. ${ }^{1}$ A proposal from the municipalities in 2006 described what they would try to accomplish in the coming decade. ${ }^{2}$

At the national level the Home Secretary published a white paper that described several scenario's regarding mid-level government. ${ }^{3}$ The minister emphasized the need for solving actual problems, clarity, integral administration, democratic legitimacy and especially a reduction of administrative crowdedness. (Biza 2006a, b: 5). The previous national government also commissioned research in this regard, that is, the De Grave Commission who was assigned the task of making recommendations to reduce administrative crowdedness. This commission focused on a clear separation of tasks and responsibilities between the several governmental layers.

At the European level there are also reports on the future of the provinces (regions). EU aims to strengthen the sub-national levels at the cost of national governments. Reports on the subject include 'Regional and Local Authority in Europe' and 'The Regional and Local Dimensions of New Forms of Governance in Europe'. It is clear that $\mathrm{EU}$ is in favor of a stronger position of mid-level government. The Council of Europe published a report that presents arguments for the protection of local government and guarantees financial, political and administrative independence. ${ }^{4}$

In addition to these actors, there is the Council for the Public Sector and the Council for Financial Relations in the Public Sector that published reports on the position of the provinces. There are also various ad hoc commissions, like those installed by the majors of the four major cities in The Netherlands. In a report commissioned by them, it was noted that the competitiveness of the industrial western part of the Dutch economy is deteriorating because of what they call the viscousness of decision-making, i.e. too many actors, interest groups and public actors. This was followed up in a commission under former Prime Minister Kok, which pleaded for a complete reorganization of the responsibilities and a new governmental level that would have the authority to make decisions. Most of the recent reports emphasize the problem of administrative crowdedness that inhibits economic development.

\section{Opinions and arguments}

This section describes the opinions of the four major players in the debate about provinces, e.g. the Association of Municipalities, the Association of Provinces, the national government and the EU.

\footnotetext{
${ }^{1}$ Zie http://www.vng.nl

${ }^{2}$ It based its opinions on a report by the scientific council "Order in Intergovernmental Relations" (1995) and on a commissioned report by the "Commission on the Future of Local Government." In that report the position of local government in 2015 is explored as well as its relation to the provinces.

3 "The future of sub-national government"

${ }^{4}$ MvT, Stukken Belgische Senaat 1999-2000, 2-214/1.
} 
According to the Association of Provinces, the tasks and responsibilities of provinces should be extended from spatial issues, infrastructure and watermanagement to care, education, youth, and welfare, because of the coordination problems, the need for coherent policies and the regional dimensions of these issues (IPO 2005: 4-5). The provinces should have a central role in managing the quality of public administration. In their opinion, provinces should take responsibility in the organization and management of public policy processes, the control of public expenditures and the smooth negotiations between public and private stakeholders. (IPO 2006b: 1). The arguments are that provinces are wellequipped for these tasks and are, in fact, the only ones who are competent in such matters. They form the joints in regional, societal and administrative networks. Furthermore, the historical position, the constitutional foundation and the democratic legitimacy of provinces justifies such an extension of tasks (IPO 2006b: 1). Provinces should not be limited in their tasks because as this organization tells us: "in order to make differentiation possible, an open household is crucial for provinces. It enables the right of taking initiatives, innovation and tailor-made solutions" (IPO 2006b: 1).

The opinions of the Association of Municipalities are in sharp contrast to this position. This organization argues for a "closed household" and a limitation of the activities of the provinces to those tasks they are made responsible for by law. The tasks should be limited to those explicitly given to them by national government (VNG 2006a). This would further the decentralization of responsibilities to municipalities, reduce administrative crowdedness, and would make the financial powers more congruent with the actual authorities (VNG 2006b). They argue for separating tasks and outlining the tasks among governmental layers, which are at present too diffuse and mingled. Based on a report from the Scientific Council, they further argue that the provinces should not have executive tasks of their own, but should control and coordinate only those tasks conducted by municipalities that have spill-over effects (WRR 1995: 36-37). It is the combination of coordinating and controlling tasks on the one hand and implementing policies on their own that makes provincial policies problematic (WRR 1995: 68).

Another point made by the Association is that provinces should not be too involved and instead should be more prudent in their involvement with policies developed by municipalities. The provinces are accused of pursuing their own aim of uniformity among municipalities and limiting possibilities for tailor-made policies and diversity between different municipalities. (Commissie Toekomst Lokaal Bestuur van de VNG 2006: 79). The solution to the problems is that provinces should be less ambitious and limit themselves to the tasks accorded to them by law, i.e. spatial planning, environmental issues, water-management, land development and strictly described control on municipal finance and intermunicipal cooperation (Commissie Toekomst Lokaal Bestuur van de VNG 2006: 79). Social cultural themes should not be part of the provincial tasks and because of this, the number of provinces could be significantly reduced (Commissie Toekomst Lokaal Bestuur van de VNG 2006: 79).

At the national government level, recent proposals propose a reduction of the number of provinces, especially in the most industrial part of the country (the West) because of the urgent problems. It points to the administrative density in that area 黑 Springer 
with three provinces, numerous large municipalities and many inter-municipal arrangements, all having partial responsibility for economic development. The problem is that all of these actors are unable to conclude discussions and come to decisions. This is judged to be detrimental for economic development and the international position of this region. (BIZA 2006a, b: 29-37).

Outside of this industrial area, the problems are assumed to be less urgent and administrative rearrangements would be less vital. It is the opinion of the Home secretary that provinces should limit themselves to oversight, developing frameworks, and mediation because these are the only tasks other governmental layers see as useful for them to be involved in (BIZA 2006a, b: 12).

This point of view is supported by several commissions appointed by the national government. The argument goes like this: since the western part can increasingly be seen as one area for working, living, recreation and economic activities, it also needs one governmental layer to be in authority. Since this area lacks decisiveness (as a result of the large number of actors), developments are hindered and are proceeding too slowly. The administrative arrangement needs to be simplified (CommissieBurgmans 2006: 5-15). This administrative density or 'crowdedness' is also mentioned by other commissions appointed by national government (e.g. the Commissie-Kok 2007).

These commissions also refer to economies of scale. They argue that an administrative rearrangement is necessary on the scale of the area as a whole, and that this would support the spatial development and the economic development of the western part of The Netherlands (Commissie-Kok 2007: 33).

Increasingly, the discussion seems to be heading toward different solutions for different parts of the country. In the industrial West, an administrative rearrangement is considered crucial. In the Northern, Eastern and Southern part of the country with less complex problems and responsibilities and no conflicts of interests, a rearrangement is seen as less necessary (ROB 2006: 11, ROB 2006: 10 and ROB 2006: 79, but see also Commission De Grave 2005: 10 and Commission Geelhoed 2002). Scale, the need for dynamics and coordination are the most important arguments for merging provinces in the West.

The fourth layer, the European Union, and especially the Committee of the Regions, favors a strong mid-level government in The Netherlands. Dutch regions should, in principle, comply with the European standards. They should develop in competitive units which, in accordance with the EU-Lisbon agreement, can manage social and economic development. The Lisbon agreement favors decentralization and large responsibilities for sub-national government. It also argues that uniformity of mid-level government in EU would be advisable since this gives the opportunities to steer those layers directly from Brussels.

\section{An analysis of the debate and the arguments}

Where one stands depends on where one sits

When analyzing the debate, it becomes clear that when one knows the position of the actor one also knows the actor's position. Municipalities and national 
government are very critical about the role of provinces, and the provinces themselves and the European actors are positive about the necessity of mid-level (regional) government.

Although there are no formal coalitions, two coalitions can be distinguished, with opposing views about the desired tasks for mid-level government, the merging, splitting or disbanding thereof and about uniform or distinct solutions for different parts of the country. It is remarkable that it is not a coalition of the sub-national levels against the national and supranational levels. That could be explained by substantive considerations.

However, the two coalitions must rather be seen as coalitions of indirectly related governmental levels. This can, in our view, only be explained by political reasons in which the division of authority plays a crucial role. The European level essentially desires less national authority whereas the national and local government benefit from weak provinces (Fig. 1).

As for the many Dutch public administration scholars involved in the debate, their opinions seem to vary with the level for which they do commissioned research. If they are paid to write a report on behalf of the provinces or Europe, the conclusions and arguments fit that coalition. If they are commissioned by municipalities or the national government, their conclusions are congruent with the views of that coalition.

There are only few PA scholars who addressed the issue independently. To be mentioned are Peters, who wrote a book about provinces with the catchy title "The Pompous Administration" (in Dutch 2007) and Derksen who wrote several articles about "the invisible layer."

\section{A dialogue among the deaf}

Is there further evidence that the debate about the provinces is political instead of substantial? This section addresses this question and seeks evidence in the arguments used in the debate. The strength of arguments can be judged by the extent to which they are consistent, have an empirical foundation and are aimed at a rebuttal of opposite arguments. When this is not the case, we can refer to the argument as a socalled "dialogue among the deaf" (van Eeten 1999). This is defined as "a policy controversy that remains deadlocked for many years, even after extensive research

Fig. 1 The two 'coalitions' regarding mid-level government
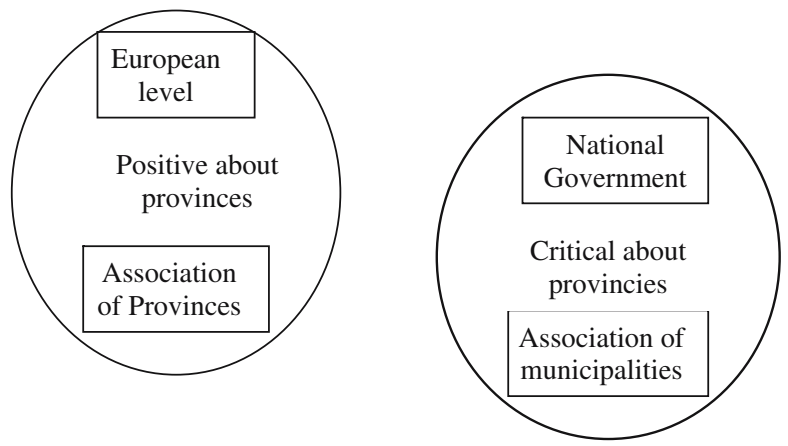
and deliberation between stakeholders. In these controversies, stakeholders talk past each other, advancing arguments that are each "true" on their own terms but that lead to fundamentally different conclusions" (van Eeten 1999).

It is clear that in the debate about provinces, the arguments are inconsistent and are not based on empirical findings nor are they related to counterarguments. Often the arguments are based on single illustrations of a process in a specific situation. Empirical evidence for the conclusions is completely lacking. It has already been argued by others that the weakness of the illustrations presented in the discussion does not allow for the strong conclusions to be drawn (RadarAdvies 2006: 23). This goes for the arguments of municipalities who argue that they are limited by the provinces and for the arguments of the provinces that their level is the most appropriate to mediate, coordinate and innovate. Given the international comparison presented earlier in which the size of mid-level government was shown to vary enormously, such a statement is hard to substantiate anyway.

The arguments about administrative crowdedness, societal developments that required upgrading administrative arrangements, economies of scale that would support a more important role for provinces, also lack empirical support. Rhetoric to convince others seems to be more important than evidence-based argumentation. It is very difficult to argue that societal problems and economic developments are structured by provincial boundaries.

With regard to consistency similar shortcomings are visible. The Association of Provinces repeatedly mentions societal developments to argue the need for provinces. They mention increasing mobility, climate change, and socio-cultural changes that require a regional approach (IPO 2006b: 4). However, they fail to argue why the provincial level would be the optimal level to address these problems. If one governmental layer exists that has remained unchanged for the last 150 years, it is the mid-level government.

Others argue for diversity and pluriformity and simultaneously plea for less complexity. However, as Hendriks argued, you cannot have it both ways. Pluriform administrative arrangements imply complex, and to some degree crowded, administrative arrangements (Hendriks et al. 2006: 10-11).

Finally, the participants rarely address each other's arguments. This is partly the result of different terminology. Where one participant talks about provinces in terms of "guarding the quality of policy processes", others use terms like "hindrance". Where some use "coordination" and "innovation," others use "crowdedness" and "administrative density." Of the total of substantial arguments given above, provinces use one half and the national and local authorities use the other half. Provinces talk about historical status, democratic legitimacy, economies of scale, assistance of local government, coordination in cases of spillover effects and guarding the quality of policies. Local governments emphasize half-hearted decentralization, standardization, duplication, lack of trust, the need for pluriformity, subsidiarity and citizen empowerment. National government stresses the administrative crowdedness, the ongoing discussions without decisions. They all seem to have different views and ideas, perceive problems differently and use rather different arguments about improving intergovernmental relations without ever truly addressing one another's arguments. 


\section{An overall analysis of the findings}

\section{Observations of the Dutch debate}

The first observation is that opinions about the provincial government are strongly related to the position of the actor holding that opinion. The proverb 'Where you stand depends on where you sit' is a well suited to describe what is going on. Actors who are positive about the mid-level government are the European Union and the Association of Provinces. They want to increase the powers and authority of the provinces and grab every opportunity for accomplishing this and to prevent others from doing the opposite. The others - municipalities and national government - just want to diminish the powers and authority thereof.

The second observation is that the underlying rationale seems to be that within a fixed territory, the mutual position of local, mid-level and national government can be seen as a zero sum power game. With several layers and a fixed territory, an increase of the powers of one, automatically results in a cost to the others. This power game seems to dominate the discussion. The problem of the layer in the middle is that it is under attack from two sides. Both national and local governments are nibbling at their powers and authority, in the same way that the provinces and EU would like to reduce national responsibilities. When a coalition between the national and local government is established, the position of the mid-level becomes especially weak. In The Netherlands, this is and often has been the case when the State Secretary had a municipal background.

Mid-level government exhibits awkward behavior in desperately trying to consolidate its position and even expand it. This is also seen in the Netherlands. The large number of functions that provinces envision for themselves and the number of policy areas they want to be involved in only serves to annoy the other two layers. This deteriorates the relationship between the provinces with the other two layers. Because of this, the provinces are not viewed as actors who make a useful contribution to the resolution of societal problems, but as actors that duplicate, complicate and disturb policy processes initiated by the other layers.

The third observation is that-perhaps as a consequence of all this - a rational debate about the proper roles and functions of mid-level governments is missing, and that any discussion that does take place can best be described as a dialogue among the deaf. It is a debate characterized by a failure to listen or react to each other's arguments, even attempting to find empirical support for one's arguments and often an amazing inconsistency in the argument's logic.

The fourth observation is that developments such as globalization and its consequences for the various governmental layers are interpreted very differently by the actors involved. Provinces see such developments as an opportunity for themselves, whereas the national and local governments view them as developments that make the provincial level redundant. All of this is argued by interpreting economies of scale by all the stakeholders to their own advantage.

For every layer, the answer to the question of the optimal scale for developing policies is different, and given the above, it is not surprising that the supposed optimum often corresponds with the territory of the claimant. Municipalities argue 
that the optimum scale should not exceed the local level because of the possibilities of public participation, the cultural differences, the differences in local problems, the specific local historical background and the merits of tailor-made policies in terms of efficiency and effectiveness. Provinces argue the same for their level. They emphasize that the extraterritorial impact every city decision has, makes some coordination necessary and that this should be the in domain of the provinces. At the national level, economies of scale are also interpreted quite differently. In this view provinces are either too small - in cases where they address those problems that extend over their territories, or too large - in cases where they try to resolve problems that could be handled by municipalities. In their opinion, very few problems remain that coincide with the classic provincial borders and that need to be handled at the provincial level. Problems either extend beyond provincial levels, or are typically local problems. Problems of public space, water, urban-rural relations, housing, economic development, poverty, health and culture could, in their view, be much better handled by municipalities or at the national level.

The possible contribution of public administration

The presentation and analysis of the case study provides the arguments for our hypothesis that in the discussion about mid-level government political strategy, rhetoric, myths, prejudice, antagonism and power games dominate. The analysis demonstrates that the discussion about the desired role, powers and authority of mid-level administration is confounded by the position and vested interests of the discussants.

The logical solution to this problem seems to be independent research addressing the subject. Such research might point out that there is a significant role to play for mid-level government, but it might also conclude that it has become a redundant layer. It might conclude that merging municipalities would be an attractive alternative for mid-level government in light of the challenges of globalization and internationalization, but it might also conclude that such mergers could be a bestpractice to be followed by upgrading mid-level government.

Because the study of public administration is framed within the disciplines of law, political science, sociology and economics, with its knowledge about governmental structures, organization and management, as well as public policy processes, it is in a position to make a significant contribution to the understandings of the necessity of mid-level government.

Many countries are faced with a three or four layered government and many P.A. colleagues I meet at conferences mention the problems arising from the multilayered structure of government. However, very little research in this field has been done so far and most of the research that is done is conducted within the framework of regional planning. Little research in this area is evidenced from scholars in public administration. What could P.A. scholars add to the discussion?

- First of all, they could fill in some of the gaps in our knowledge. Independent evaluation of the workings of mid-level government adds to our knowledge of the merits of that layer. Especially in a comparative context, this might add to the quality of the discussion about this type of government. 
- Second, not only could they conduct research into whether policies developed at the mid-level are effective and efficient, but also whether this layer is the most natural layer to conduct such policies, seen within the structure of intergovernmental relations.

- Third, they could focus their research on the development of a framework to judge the policies and position of mid-level government. At present there is no framework to judge their actions. There are no evaluations conducted within such a framework about their actual behavior, besides those initiated by the provinces themselves which are, to say the least, often biased.

- Fourth, they could provide comparative research into the causal mechanisms that determine the necessity or redundancy of the provincial level-especially in order to test hypotheses about the need of mid-level government. It might be the case that a mid-level government is needed more in larger countries, in countries where communication between national and local level is problematic, or in countries where socio-cultural and socio-economic problems are more varied. The hypotheses are there, the research into their validity is still missing.

There are many myths surrounding mid-level government, many developments that might affect its position, and much criticism that disputes its role, power, authority and even 'raison d'etre.' It might be that its malfunctioning is a major cause for the negative image of the public sector, but it might also be the only governmental layer that is not too far from the everyday problems, but still has enough distance to reflect on those problems. Perhaps it is the only stable factor in an ever changing world, or maybe it is an outlived historical aberration.

The answer to questions as these will most likely vary over countries and different parts of world. Perhaps a mid-level government is needed more in developing countries than in developed countries or vice versa. Perhaps there are more variables at stake than just the level of development. The point is that it is necessary to debunk the myths, test the claims as if they were hypotheses and ultimately develop a framework to judge and evaluate the existing intergovernmental structures. We advocate for the construction of a framework to evaluate when and where local, regional and national government should take prime responsibility over policy areas and to fill this framework with empirical findings.

This article presented the example of the discussion in The Netherlands. The reconstruction of the debate might not be so different from the same debates taking place in other advanced industrial countries as well as in developing countries, but perhaps the arguments used are very different. Comparatively speaking, we simply lack knowledge to present a fair judgment about mid-level government.

Our assumption would be that such debates are without consequence because different opinions and interests are hardly ever resolved. Sometimes the decisions about intergovernmental relations are concluded. In the Republic of South Africa, for instance, in 2005, the Intergovernmental Relations Framework Act was passed. It aims to bring about coherent government, effective provision of services, monitoring implementation of policy and legislation, and realization of national priorities. The act tells its governments that in conducting their affairs the national government, provincial governments and local governments must seek to achieve the object of this Act by taking into account the circumstances, material interests and budgets of 
other governments and organs of state in other governments, when exercising their statutory powers or performing their statutory functions. In other words, the act is developed in order to establish procedures for the conflicts that can, and probably did, arise between different governmental levels.

\section{Conclusions}

In this article, we addressed the debate about the proper role, functions, powers and responsibilities of mid-level government. We began with the observation that the level in-between the local and the national government is problematic and that its function is indeterminate. Second, we addressed the ongoing discussion about the provinces in the Netherlands. We argued that the opinions expressed in this discussion are mostly based on the vested interests of the participants who are caught in a zero-sum power game and not on substantive information. The arguments in the discussion are based on dubious assumptions and lack an empirical foundation. They are neither consistent nor do they address counter-arguments. Some participants emphasize administrative crowdedness, others the needed economic development, the historic position of the provinces and societal developments. This does not lead to a constructive debate. When one knows the position of a participant, one also knows his opinion.

Subsequently we investigated the possible role of P.A. scholars in this debate. We argued that these scholars can conduct independent evaluations of processes taking place at the mid-level layer of government; investigate whether the provincial level is the right level to develop policies to solve specific policy problems; develop a general framework to judge the policies and position of mid level government; and conduct comparative research into the causal mechanisms that determine the need of mid-level government. This contribution is nearly absent.

In many countries, a governmental layer exists in between the national and local level. In Public Administration, this layer is neglected. Most scholars are either interested in local or national developments. In our view, the mid-level is as important as the local and national levels because of its involvement in many policy processes as well as for explaining the developments at the other levels.

It is expedient to improve the discussion about this governmental level by making evidence based, valid and reliable information available. The development of a general framework, in which all the relevant criteria to judge mid-level government are included, could serve to push the debate in a direction in which actors with a vested interest are forced to react to one another, base their arguments on factual information and in which the discussion could focus on the relative weight of those criteria.

In this way we can perhaps arrive at a fair evaluation on the position of mid-level government and see whether they are archaic and redundant institutions or have the added value they profess to have, or.... are something in between.

Open Access This article is distributed under the terms of the Creative Commons Attribution Noncommercial License which permits any noncommercial use, distribution, and reproduction in any medium, provided the original author(s) and source are credited. 


\section{References}

Ad hoc Adviescommissie Regionaal Bestuur in Nederland (Commissie-Geelhoed) 2002. Op schaal gewogen. Regionaal bestuur in Nederland in de 21ste eeuw. The Hague: uitgave van de IPO.

Adviescommissie Commissie Versterking Randstad (Commissie-Kok), 2007. Advies commissie versterking Randstad.

Adviescommissie G4-Manifest (Commissie-Burgmans), 2006. G4@RandstadHolland.EU. Randstad Holland in een globaliserende wereld. Advies ten behoeve van de kabinetsformatie, opgesteld op verzoek van de vier grote steden.

Andrews, C., \& de Vries, M. S. 2007. High expectations, varying outcomes: Decentralization and participation in Brazil, Japan, Russia, and Sweden. International Review of Administrative Sciences, 73(3): 424-451.

BIZA, Ministerie van Binnenlandse Zaken en Koninkrijksrelaties, 2006a. De toekomst van het decentrale bestuur, het decentrale bestuur van de toekomst. The Hague.

BIZA, Ministerie van Binnenlandse Zaken en Koninkrijksrelaties, Thorbeckediner, 2006b. Opschaling en verdunning in het middenbestuur. Zoetermeer.

Boogers, M. 2000. Over modernisering van lokaal bestuur. In: Nelissen, N., Goverde, H. \& Gestel, van, N. (Eds.). Bestuurlijk vermogen: analyse en beoordeling van nieuwe vormen van besturen: 325-353. Bussum: Coutinho.

Commissie Toekomst Lokaal Bestuur van de VNG (2006). Wil tot verschil. Gemeenten in 2015. The Hague.

Denhart, R. 2002. Trust as capacity: The role of integrity and responsiveness. Public Organization Review, 2(1): $65-76$.

de Vries, M. S. 2000. The rise and fall of decentralization: A comparative analysis of arguments and practices in European countries. European Journal of Political Research, 38: 193-224.

de Vries, M. S. 2004. Institutional fleecing: The slow death of Dutch provinces. Public Organization Review, 4(4): 295-315.

DiMento, J. F., \& Graymer, L. 1991. Confronting regional challenges: Approaches toLULUs, growth, and other vexing governance problems. Cambridge, MA: The Institute.

Dowling, J. 2003. The rise of regionalism in the European Union. London: Kings College, International Boundary Studies.

Farazmand, A. (Ed.) 2004. Sound governance: Policy and administrative innovations. London: Praeger.

Frug, G. E. 2000. Against centralization. Buffalo Law Review, 48(1): 31-38.

Gemengde Commissie Bestuurlijke Coördinatie (Commission-De Grave), 2005. Je gaat er over of niet. Rijksbrede takenanalyse.

Guy Peters, B. 1996. The future of governing: Four emerging models. Lawrence: University Press of Kansas.

Hendriks, F., et al. 2006. Wil tot verschil of wil tot macht? Een reflectie vanuit de bestuurskunde en het bestuursrecht. Tilburg.

IPO, Interprovinciaal Overleg, 2005. Profiel van de provincies: pasvorm of pluriform, discussienotitie. The Hague.

IPO, Interprovinciaal Overleg, 2006a. Jaarplan 2007. The Hague.

IPO, Interprovinciaal Overleg, 2006b. De provincies in het middenbestuur.Reactie IPO op discussienotitie 'Maatwerk in het middenbestuur'. The Hague.

Jacob, J. 1984. Cities and the wealth of nations: Principles of economic life. New York: Random House.

Kahler, M., \& Lake, D. (Eds.) 2003. Governance in a global economy. Princeton: Princeton University Press.

Katz, B. (Ed.) 2000. Reflections on regionalism. Washington, DC: Brookings.

Kresl, P. K., \& Gappert, G. (Eds.) 1995. North American cities and the global economy: Challenges and Opportunities. Thousand Oaks, CA: Sage.

Osborne, D., \& Gaebler, T. 1992. Reinventing government: How the entrepreneurial spirit is transforming the public sector. New York: Penguin.

Ostrom, E. 1990. Governing the Commons. Cambridge: Cambridge University Press.

Peters, K. 2007a. Het opgeblazen bestuur. Een kritische kijk op de provincie. Amsterdam.

Peters, K. 2007b. Provincies beter af zonder verkiezingen. In Binnenlands Bestuur, pp. 26-29.

Prud'homme, R. 1995. The dangers of decentralization. World Bank Research Observer, 10: 201-220.

RadarAdvies, 2006. 'Last hebben van elkaar'. Een onderzoek naar voorbeelden waar provincie en gemeente elkaar tegenkomen. Amsterdam. 
ROB, 2006. Bestuur op maat. Advies over middenbestuur. The Hague.

Schechter, B. 1996. Metropolitan governance: A bibliographic essay. National Civic Review, 85(2): 337341.

van Eeten, M. 1999. Dialogues of the deaf: Defining new agendas for environmental deadlocks. Delft: Eburon.

VNG, Vereniging van Nederlandse Gemeenten, 2006a. Ledenbrief 06/148 d.d. 22-09-2006. The Hague. VNG, Vereniging van Nederlandse Gemeenten, 2006b. Brief aan het bestuur van het IPO d.d. 9-11-2006. The Hague.

WRR, Wetenschappelijke Raad voor het Regeringsbeleid, 1995. Orde in het binnenlands bestuur, The Hague. 